\title{
On the Nature of Polylopia
}

GEOLOGICAL SURVEY PROFESSIONAL PAPER 593-F

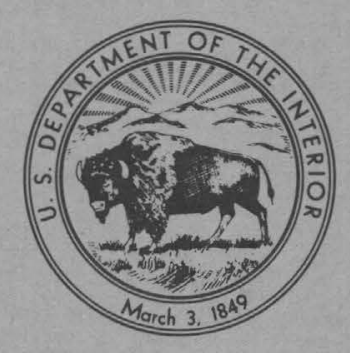





\section{On the Nature of Polylopia}

By ELLIS L. YOCHELSON

CONTRIBUTIONS TO PALEONTOLOGY

GEOLOGICAL SURVEY PROFESIONAL PAPER 593-F

$A$ reinvestigation of a rare Middle

Ordovician conical mollusk

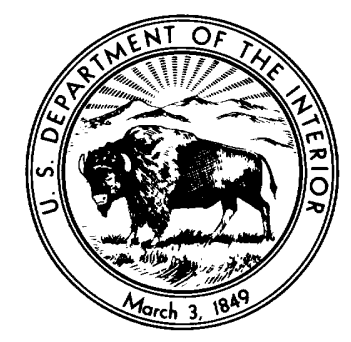

UNITED STATES GOVERNMENT PRINTING OFFICE, WASHINGTON : 1968 
UNITED STATES DEPARTMENT OF THE INTERIOR

STEWART L. UDALL, Secretary

GEOLOGICAL SURVEY

William T. Pecora, Director

For sale by the Superintendent of Documents, U.S. Government Printing Office

Washington, D.C. 20402 - Price 20 cents (paper cover) 


\section{CONTENTS}

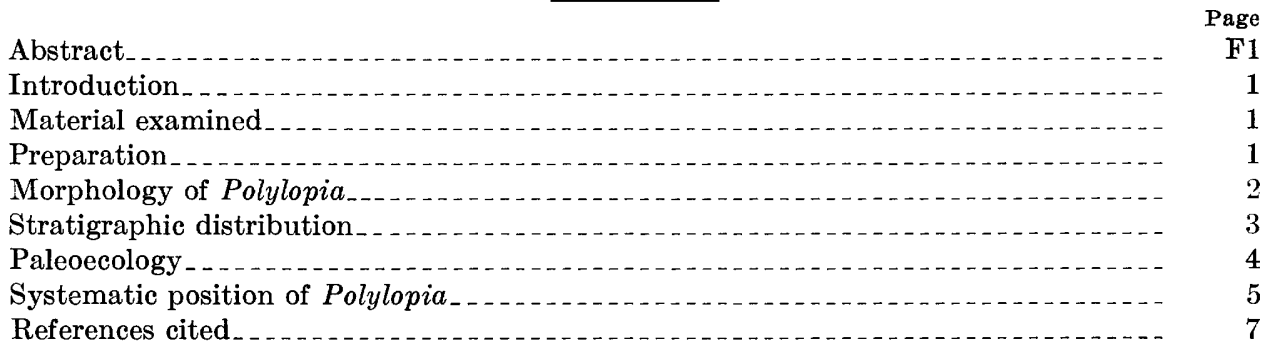

\section{PLATE}

[Plate follows references cited]

1. Polylopia and Biconculites. 



\title{
CONTRIBUTIONS TO PALEONTOLOGY
}

\section{ON THE NATURE OF POLYLOPIA}

\author{
By Eutis L. Yochelson
}

\begin{abstract}
Polylopia billingsi (Safford), from the Middle Ordovician Murfreesboro Limestone of central Tennessee, is redescribed. The shell is interpreted as a simple exceedingly high closed cone, bearing longitudinal lirae on the exterior and lacking any interior structures. Earlier workers had interpreted Polylopia as a multilayered shell open at both ends. The apparent multilayering is here judged to be nesting of shells after death.

Polylopia billingsi also has been recorded from Middle Ordovician rocks in Indiana. New occurrences in eastern Tennessee and Minnesota are herein reported; a report of the genus in Virginia is questioned. All known occurrences of the taxon are from beds of Middle Ordovician age, from the Porterfield and Wilderness Stages.

The biologic position of Polylopia is enigmatic; it is interpreted as a mollusk and questionably associated as a separate family within the subclass Orthothecida of class Hyolitha. The animal may have been a benthonic form living in extremely shallow marine water, and the apex of the shell could have been lightened by gas.
\end{abstract}

\section{INTRODUCTION}

In his paper "On the nature of Salterella," Clark (1925) recognized the distinctiveness of Middle Ordovician Salterella billingsi Safford from true Cambrian Salterella and proposed the genus Polylopia to encompass it. Fisher (1958) has written the most definitive work on the morphology and biologic placement of the genus. He originally suggested (Fisher, 1958, p. 145) that it was a scaphopod, though subsequently (Fisher, 1962 , p. W134) its molluscan assignment was left open. Emerson (1962, p. 480-481) questioned its placement within Scaphopoda. New material has prompted a reinvestigation of this form, and has resulted in conclusions regarding its morphology which are somewhat at variance with those published earlier.

This work has been substantially aided through discussion and critical reading of the manuscript by several colleagues. In this regard, I owe particular debts to Dr. Donald W. Fisher, New York State Museum, Dr. Rousseau H. Flower, New Mexico Bureau of Mines and Mineral Resources, and Dr. Ladislav Marek, Czechoslovak Academy of Sciences. As with any scientific work, responsibility for the conclusions rests solely with the author.

\section{MATERIAL EXAMINED}

Polylopia is best known from outcrops of the Murfreesboro Limestone, exposed along Stones River near Murfreesboro, Tenn. (Safford, 1869, p. 261; Bassler, 1932 , p. 50-52). This formation, the oldest of the Stones River Group and the oldest Middle Ordovician stratum exposed in the central basin of Tennessee, was a collecting area favored by E. O. Ulrich and R. S. Bassler. A modest collection of specimens at the U.S. National Museum is mainly the result of their work.

Recently, Mr. William H. Workman, of Murfreesboro, Tenn., donated a large block of Murfreesboro Limestone to the U.S. National Museum. It was obtained about 0.45 mile southeast of the Stones River Bridge on the north side of a new interstate highway leading northwest out of Murfreesboro. This block, blasted free during road construction, contained a remarkable number of Polylopia specimens which have figured prominently in this study.

Dr. Robert C. Milici, Tennessee Division of Geology, kindly contributed several specimens obtained during mapping in the Sequatchie Valley of eastern Tennessee. Finally, a small collection from Minnesota, now in the U.S. National Museum, provided additional new information.

\section{PREPARATION}

Fossils from the Murfreesboro Limestone characteristically are chertified. Although the chert is dark gray to black, both fossils and rock which have been exposed to the surface are stained a rich reddish brown by iron oxide. In the past years, chertified fossils have been obtained loose in residual soils or attached to chert slabs. As a consequence of this replacement, preparation and observation of fossils has been restricted.

The Murfreesboro Limestone material submitted by Mr. Workman consisted of a large tabular chert mass 
about 2 by 3 feet and about 6 inches thick. To facilitate its handling, Carl Hershey, Department of Mineral Sciences, U.S. National Museum, sawed the boulder into blocks $6-12$ inches in diameter. During this preparation, it was noted that not all the rock was chertified; some lenses of limestone remained within the chert. These blocks were then dissolved in hydrochloric acid and yielded silicified fossils from the limestone lenses.

Almost all the fossils in the limestone lenses were silicified; but differential replacement had taken place, and a few chips of limestone containing calcareous Polylopia were finally located. William C. Pinkney, Jr., U.S. Geological Survey, prepared half a dozen thin sections from these chips. One thin section from the calcareous material from Minnesota was also prepared. Specimens from eastern Tennessee are on a small piece of chert; no preparation of these specimens was attempted.

\section{MORPHOLOGY OF POLYLOPIA}

Clark (1925) applied a descriptive generic name to this taxon; the etymology is Greek for trees with many layers of bark. The character considered significant by all investigators has been a multiple number of shell layers. Safford (1869, p. 289) indicated "at least three cones, one within the other." Clark (1925) discussed "cones, one within the other," though he did not give a specific number of cones. Fisher (1958, p. 145) observed that the "number of shell layers is not constant," for some specimens show one to five layers, and the average have three to four.

Billings (1861, p. 17) described Salterella as "several hollow cones placed one within another, ***" Presumably, because of this description, Safford assigned his Middle Ordovician fossil to that Lower Cambrian genus. However, Lochman $(1952$, p. 86 ) has noted that the apparent cone-in-cone feature of Salterella is an artificial effect. If the outer part of the shell is removed, selected inner laminae of a salterella are accentuated by weathering. This effect is shown by individual specimens and is not a result of packing. Investigation of several dozen thin sections of Salterella from Pennsylvania, Nevada, and Mexico has shown no examples of nested shells, and fully supports Lochman's interpretation.

The question of the number of shell layers of Polylopia is a major point of disagreement among workers. The variable number of invaginated cones, referred to by previous investigators, is here judged to be entirely unrelated to the true morphology. It seems to be nothing more than a postmortem penecontemporaneous packing phenomenon. Several lines of evidence lead to this conclusion.
Although it has been stated that specimens of Polylopia are randomly arranged within the matrix, these elongate shells are usually oriented with long axes parallel to each other. On the bedding surfaces examined, no specimens were observed to deviate more than a few degrees from the principal line of orientation (pl. 1, fig. 1). No clear preferred orientation exists for the wider or narrower end of the cone, presumably because it tapers so gradually. Three layers of closely spaced oriented Polylopia are present within the 6-inch thickness of one block. Each layer shows distinct orientation of specimens, and the principal direction of orientation is different for each layer. A small fragment might not show obvious orientation, however, and a block of chert split at right angles to the bedding plane, a characteristic of this rock, would suggest random orientation of the specimens.

Direct evidence of packing of the cone-shaped shells is shown by specimens which have another shell at an angle to the larger shell enclosing it, so that the supposed shell walls are in contact at one place but separated by matrix at another (pl. 1, figs. 2, 5-8). In other examples, a juvenile shell is closer to one edge of an outer cone than to the opposite edge, as viewed in longitudinal section (pl. 1, figs. 11-13). The most compelling indication that the numerous cones do not represent a growth phenomenon is the discovery of several juvenile shells within a larger cone (pl. 1, fig. 14).

The fit of one Polylopia shell within another may be remarkably close. Given only a small amount of material to examine, one can understand an interpretation of it as a multilayered shell. The hydrodynamic forces needed to cause this close nesting of cones are not understood, but there is no question that such nesting has occurred.

Secondary nesting is a particularly subtle trap to avoid when dealing with conical shells and tubes. To cite one further example, a slightly curved tubular Early Cambrian organism, Biconutites Teilhard de Chardin (1931), is clearly based on spurious characters formed by the insertion of one or more specimens of Hyolithes into another Hyolithes (Kobayashi, 1937; Spath, 1936) ; accordingly, it has no significant biologic or precise stratigraphic meaning. A specimen referred to Biconulites (pl. 1, fig. 9) is illustrated for comparison with the secondary nesting in Polylopia.

The true nature of the Polylopia shell is not known. Thin sections of calcareous specimens from Tennessee and from Minneosta show that the shell is composed of recrystallized calcite (pl. 1, figs. 11,14); thin sections of chertified material show that the replacement is too coarse to preserve relic structure. The number of original shell layers cannot be determined. Nothing can be 
said of the original mineral composition except that it was probably calcium carbonate in one or more crystal states. The loss of internal layering suggests that the original material might have been aragonite in part rather than calcite. Shell thickness seems to increase aperturally at a uniform rate in relation to the width of specimens (pl. 1, fig. 10). The maximum wall thickness at the aperture of large specimens is near $0.25 \mathrm{~mm}$.

All specimens seem to be circular in cross section (pl. 1, figs. 2, 5, 6). No oval or elliptical specimens were observed, though this form of cross section may appear in randomly oriented thin sections (pl. 1, fig. 14). In a few silicified specimens the juvenile part of the shell has been broken and the break healed by silica (pl. 1, figs. 3, 4), but, without exception, no curved specimens were observed. Thus, all specimens seem to taper at a uniform rate, and a hypothetical central axis is a straight line. If the shell is logarithmically curved rather than tapered, the angle of logarithmic curvature must be almost zero. By comparison, the slight curvature of typical hyolithids and scaphopods is at an angle of $3^{\circ}-5^{\circ}$.

The juvenile part of specimens, where preserved, tapers to a point, a true closed apex (pl. 1, figs. 10,11). Although many specimens are broken, a substantial number retain shell apices of such small size as to rule out effectively the presence of an apical opening (pl. 1, figs. 11-13). Interpretation of the shell of Polylopia as a closed cone is another point of variance with the interpretation of earlier workers who considered it open at the apex.

No internal shell deposits are known. Several random broken specimens show no secondary material deposited on the interior of the shell wall; the apex is not filled with calcite (pl. 1, fig. 10). The exceedingly deep penetration of one shell into another indicates the absence of septa within the shell, an observation confirmed by the thin sections (pl. 1, figs. 10-13).

The exterior of the shell is ornamented by closely spaced longitudinal lirae (ridges). The lirae are distinctly raised above the shell surface; they are low and rounded, though this may be the result of secondary wear. Interspaces are no more than twice as wide as the individual lira. The lirae diverge with maturity, but also widen uniformly. As far as can be determined, each lira extends from near the apex to the mature aperture, though silicification obscures details. The placement of ornament near the apex is not clear. On all specimens observed there was no indication of intercalation. Because of the silicification and local breakage, it is impossible to count the exact number of lirae; about 30 seems to be a reasonable approximation.

The shell surface between lirae is smooth. No break is seen in any of the lirae, and no growth lines have been observed. A few specimens show slight, broad furrows normal to the growth axis, and it is possible that these furrows are parallel to growth lines. None of the specimens preserves an unbroken aperture.

To summarize, a formal diagnosis of Polylopia is: Shell an elongate tapering cone, expanding uniformly at an angle of about $2.5^{\circ}$, at maturity at least $10 \mathrm{~cm}$ long; number of shell layers unknown; cone without any interior secondary deposits; exterior ornamented by low longitudinal lirae, commonly about thirty around the aperture of a mature specimen.

All material examined shows little individual variation and thus gives no jusification for recognizing more than one species of Polylopia. Except for the central basin occurrence at Murfreesboro, Tenn., specimens are too rare or fragmentary to permit meaningful comparison at the specific level. In the present state of knowledge, it is difficult to differentiate morphologic features of specific generic rank. Diagnoses of the genus and of Polylopia billingsi (Safford) are therefore identical.

Fisher (1958, p. 144) noted that a slab, USNM 15247, has a label "apparently in Safford's handwriting." The disposition of Safford's material seems to be unknown. The handwriting is also similar to that of Charles Schuchert, though the possibility of this label being Safford's cannot be ruled out. Schuchert (1905) does not list Salterella billingsi in the collections of the U.S. National Museum.

Fisher's illustrated material has been recataloged under USNM 157844-157853. To avoid any nomenclatural confusion, a neotype of Polylopia billingsi should be designated. The long specimen to the right of an illustrated slab and directly below a pelecypod fragment (Fisher, 1958, pl. 23, fig. 10; USNM 157844) shows most significant features and is here designated as neotype.

\section{STRATIGRAPHIC DISTRIBUTION}

Polylopia is best known from the Murfreesboro Limestone of the Stones River Group. Although this occurrence has been reported several times in the literature, these supplementary reports have not contributed significant new information. The central basin is a structurally simple eroded dome, and only the upper part of the Murfreesboro Limestone is exposed. Bassler (1932, p. 50) reported Polylopia about 20 feet below the top of the formation. The type species, $P$. billingsi (Safford, 1869 , p. 289), was originally described as ranging from the "Central Limestone" (Murfreesboro Limestone) through the "Glade Limestone" (Carters Limestone). No Tennessee material of post-Murfreesboro age, however, has been reported by subsequent investigators. Safford's original material from the "Glade" is lost, 
and the stratigraphic range given by him cannot be verified. The Murfreesboro is assigned to the upper part of the Porterfield Stage (Cooper, G. A., 1956, chart), and the Carters occurrence, if verified, would extend the range of Polylopia to the upper Wilderness Stage of G. A. Cooper.

In the Sequatchie Valley of eastern Tennessee, Polylopia occurs in Murfreesboro chert above the post-Knox unconformity, (R. C. Milici, written commun., 1966). This chert crops out along the Alvin C. York Highway about 0.1 mile east of the crossing of the highway and the Nashville, Chattanooga, and St. Louis Railroad right-of-way, in the Pikeville, Tenn., 71/2-minute quadrangle, about 2 miles southwest of Pikeville. Specimens of Polylopia are found with the characteristic Murfreesboro gastropod Helicotoma and the ostracode Leperditia (USNM 157890). Other typical Murfreesboro mollusks and brachiopods are present in the soil on residual cherts, but it is unlikely that many are from the same bedding plane. This Polylopia occurrence is at the base of the Murfreesboro and may have a stratigraphic separation of as much as 450 feet from the central basin material. The Pikeville specimens cannot be specifically identified.

Polylopia billingsi has also been described from the Kentland disturbed area in Indiana (Shrock and Raasch, 1937, p. 570, pl. 7, figs. 16, 17). It occurs with a fauna generally similar to that of the type Murfreesboro Limestone, though the structure and subsequent erosion of this collecting site (Shrock and Malott, 1933) make it impossible to compile a precise list of associated taxa. G. A. Cooper (1956 p. 106-108) indicates that divisions 4-6 of Kentland section, one or more of which yielded Polylopia, are probably equivalent to the upper half of the Wilderness Stage, even though Shrock and Raasch (1937) suggested that the presence of Polylopia was indicative of correlation with the type Murfreesboro.

The occurrence of Polylopia in Minnesota supports the suggestion that the genus ranges through the Porterfield and Wilderness Stages (Cooper, G. A., 1956). In 1906, E. O. Ulrich collected specimens from the "Black River group, Ctenodonta bed, 5 miles south of Cannon Falls," [part of the Guttenberg Limestone Member of the Decorah Formation (Cooper, G. A., 1956, p. 111) ] (USNM 50114-50115). Ulrich identified the Minnesota specimens as "near Salterella billingsi," though the material is not well-enough preserved to determine if $P$. billingsi is the species present. Although the genus cannot be used as a precise time indicator at the stage level, it probably indicates a specialized facies during a rather narrow span of Middle Ordovician time.

As far as it is known, Polylopia has been reported at only one other locality. B. N. Cooper and C. E. Prouty (1943, p. 830-831) list P. billingsi from their Peery Limestone Member of their Cliffield Formation in Tazewell County, Va. B. N. Cooper (1945, p. 271) correlates the Peery with the Murfreesboro, though G. A. Cooper (1956, chart) indicates that the Peery is slightly older and correlates it with the lower part of the Porterfield Stage.

The material upon which G. A. Cooper and C. E. Prouty based their fossil list is not available. Some years ago I collected three straight fragmentary tubes from the Peery Limestone of Cooper and Prouty. These tubes have more prominent longitudinal ornament, approximately twice as widely spaced as that of Polylopia billingsi, and are larger in diameter. There is little question that they should be referred to the orthoconic cephalopod Kionoceras. This genus ranges from Chazyan throughout the Ordovician (Flower, 1952, p. 35-36). While I cannot prove that Cooper and Prouty misidentified Kionoceras as Polylopia, the two are superficially similar and such a mistake might easily have been made.

\section{PALEOECOLOGY}

In the material from Murfreesboro, Tenn., Polylopia occurs in profusion along some bedding planes, to the virtual exclusion of all other fossils. Between these layers, scattered fossils occur with abundant Helicotoma, other snails, and the ostracode Leperditia. If specimens were collected loose in the soil, one would assume that these forms lived together, whereas Polylopia may have lived in a separate ecotope.

Detailed mapping of the tpe Murfreesboro by Oscar B. Hofstetter III, University of Tennessee, has shown that distribution of Polylopia is erratic in the outcrops along Stones River (written commun., 1966). The large number of mollusks in the Murfreesboro Limestone and the profusion of ostracodes suggest shallow, near-shore marine conditions. Brachiopods and bryozoans are absent on the bedding planes which contain a profusion of Polylopia, and they are extremely rare where specimens of the genus occur with other typical mollusks. Orientation of specimens implies current action, at least after death of the specimens. The limestone matrix contains little clay and is rather pure, except for the large masses of chert. Wilson (1949, p. 334-336) has reported mud cracks from the type Murfreesboro. Thus, there are several indications that Polylopia lived in marine waters, possibly varying slightly from normal open-sea salinity, at depths shallower than 100 feet.

Regarding the eastern Tennessee occurrence, Milici (written commun., 1966) writes: 
In Sequatchie Valley the basal Murfreesboro contains limestone and chert conglomerates, with fragments up to 3 inches in size. In one place a dolomite pinnacle of Knox protrudes about 15 feet upward into the Murfreesboro, and the rocks just above the Knox and around the pinnacle appear to be a nowconsolidated dolomite sand bar. Most of the overlying Murfreesboro in Sequatchie Valley is calcilutite, although shaly limestones are common. Except for the Pikeville chert locality, the Murfreesboro contains only a few fossils. Shallow water features, such as mud cracks and ripple marks, are common throughout the Middle Ordovician sequence, and it appears that you are on good ground with a shallow water marine environment-and particularly shallow just above the drowned Knox erosion surface.

As noted on page F4 no assemblages or ecologic observations can be drawn from the occurrence in Kentland, Ind. The Minnesota specimens are isolated in a museum tray, and it is now impossible to determine what other fossils, if any, were associated with them. The general locality is well known for the excellent fossil mollusks it has yielded.

It is difficult to interpret the life habit of Polylopia from the standpoint of functional morphology. The rather long shell is not closely comparable to that of Recent Pteropoda. The solid construction and relatively heavy weight of this narrow cone tend to rule out any planktonic or nektonic habit as is ascribed to both chambered cephalopods and thin-shelled pteropods.

Because the shell is closed at the apex, Polylopia probably could not have lived with soft parts under the mud-water interface. Problems of water circulation in burrowing pelecypods are solved by siphons extending to the water surface; scaphopods circulate water through the posterior (apical) opening which remains in the water when the apertural part of the shell is in the substrate. It is unlikely that the aperture and anterior soft parts of Polylopia were in sediment for any extended period of time, if at all.

It seems most reasonable to suggest a benthonic habit in preference to either a planktonic or burrowing mode of life. However, the circular cross section and the uniform distribution of longitudinal lirae hint that the shell did not lie on the bottom during life. Even if the animal were able to deposit a symmetrical shell while lying on the bottom, it is difficult to understand how the animal could exclude sediment particles from the aperture. If the bottom were moderately soft, the problem would likely be insurmountable.

The most likely hypothesis is that during life the shell was carried with aperture downward and apex upward. The long slender cone provided enough room for trapped gas which could have increased the buoyancy of the apical portion. Even without the ability to move far forward in the shell by constructing septa, Polylopia might have been able to move its soft parts a few millimeters forward in the shell to form an apical cavity.

The absence of septa and a siphuncle in Polylopia places any functional comparison with cephalopods on a most uncertain basis. Still, there may be some slight support for the hypothesis of a buoyant apex in that the gradual taper of the Polylopia shell and that of many Ordovician orthoconic cephalopods is qualitatively similar. Were Polylopia a more rapidly expanding cone, it might have been far more difficult for soft parts to move forward than it would have been in a slowly expanding cone. Admittedly, the concept of an apically gas-lightened shell carried erect by an animal creeping over a fairly firm bottom is difficult to accept. Nevertheless, this hypothesis seems to explain the combination of radial growth, gentle taper, closed apex, and substantial shell thickness. One can hope for little more with such a curious fossil as Polylopia.

\section{SYSTEMATIC POSITION OF POLYLOPIA}

The molluscan nature of Polylopia is generally accepted (Shimer and Shrock, 1944, p. 533) but is diffcult to demonstrate. Only indirect evidence supports placement of the genus within this phylum. The shell is regular and expands at a uniform rate; these features eliminate many worm tubes, though not all of them. The rather spongy and coarse silicification of the Murfreesboro material is comparable to that of undoubted mollusks in the same block of limestone.

It is unfortunate that no information is available on the original composition and structure of the shell, as this might support the placement of Polylopia among the mollusks. In spite of the paucity of evidence pointing toward the Mollusca, there is no reason to question this placement. Transfer to another phylum seems to be even less satisfactory. The entire question of which fossils should be placed in the phylum Mollusca and which should be rejected has not received intensive study (Yochelson, 1961b). Although I am confident that Polylopia is a mollusk, the conclusion must be considered tentative, at best.

The position of Polylopia within the phylum Mollusca is even more of an enigma than its phyletic position, if indeed that question can be considered as settled. Polylopia does not show characters which permit ready assignment to any of the known classes of Mollusea. Several classes of mollusks based only on fossils have been proposed. Some proposals have been generally accepted; others have been rejected. I have suggested that there may be a number of extinct classes in the early Paleozoic (Yochelson, 1963).

It is within the realm of possibility that Polylopia could be the sole representative of an extinct class. One 
objection to such a proposal might be that the Middle Ordovician occurrence of Polylopia is somewhat later in the geologic record than the first occurrence of most other forms that I would accept as biologically valid bases for extinct molluscan classes. This is a spurious argument, for recognition of specimens of the class Scaphopoda in the middle Paleozoic, regardless of whether Polylopia is placed in that taxon, shows that origin of class-rank taxa within the phylum is not confined to even the broad time span of the early Paleozoic.

Another objection is that it is piling one complication onto another to provide a class-rank taxon for each peculiar fossil mollusk genus. The number of classes within a phylum is not sacred, but it is nothing more than a summary of prevalent concepts of major diversification. Nevertheless, the distinctiveness of morphology from that of recognized classes should be the prime consideration, and one might argue that the morphology of Polylopia is distinct enough to warrant such a consideration. Any judgment on this matter must be entirely subjective and, in this instance, the fossil in question is not judged to meet this criterion of major level distinctiveness.

Because I have concluded that the hard-part and inferred soft-part morphology of Polylopia is not distinctive enough to warrant the erection of a new class, the alternative position is to attempt to fit this genus into one of the accepted molluscan classes. Fisher (1962, p. W134) has suggested that if Polylopia is not placed with the Scaphopoda, the genus "still deserving a molluscan assignment should be placed with the coleolids ***"; enough uncertainty surrounds the phyletic assignment of Coleolus that I prefer not to explore this possibility in detail.

At least three mollusk classes which include animals with a tubular shell should be considered. First, the orthoconic Cephalopoda are readily distinguished by the presence of septa and, especially, by the presence of a siphuncle; differentiating the nonseptate body chamber of an externally lirate form, such as Kionoceras, from Polylopia is a special problem. Second, the Scaphopoda are distinguished by having the shell open at both ends. Third, the Hyolitha (Marek and Yochelson, 1964) have a shell closed at the apical end; placement of Polylopia in this class cannot be readily dismissed.

Evidence is increasing that the key feature of Cephalopoda, if use of such a term may be permitted, is the presence of a siphuncle and not simply the presence of septa. Some species of Hyolithes (Zázvorka, 1930) have septa, and it is common knowledge that many gastropods contain septa. It is therefore apparent that presence or absence of septa in Gastropoda and Hyolitha is not a feature of class rank. The absence of septa in
Polylopia and the presence of septa in some Hyolithes do not necessarily preclude consideration of them as both being in the same class.

Characteristic representatives of the Hyolitha show typical logarithmic spiral growth, though the angular rate of expension is very low and is comparable to that of the Scaphopoda. The Cephalopoda run the gamut in shell form, from tightly coiled forms to straight cones. This feature represents a far greater difference in shell coiling within the Cephalopoda class than exists between typical representatives of the Hyolitha and Polylopia.

The class Hyolitha is divided into two others: Hyolithida and Orthothecida (Marek, 1966). The Orthothecida differ from the typical order in lacking the basal apertural projection, termed the "shelf." Most show a quadrangular or trigonal cross section like the Hyolithida, although Orthotheca Sysoiev includes species having a circular cross section. Marek (written commun., 1967) is studying two species of Tremadocian orthothecids which have fine longitudinal ornament and a circular cross section. The conchs of these forms are slightly curved and the opercula are elliptical, which indicate that the aperture was somewhat oblique. These new taxa partly span the morphologic gap between typical Orthotheca and Polylopia.

Because Orthotheca has a slightly curved shell and typically a bilaterally symmetrical cross section, it probably rested on the bottom and, like Hyolithes, may have been incapable of much movement (Yochelson, 1961a). Polylopia lacks the features of the Hyolitha which imply a benthonic habit. If the hypothesis concerning the ecology of Polylopia is correct, this animal could represent an unsuccessful attempt at radiation or diversification by an orthothecoid becoming more mobile-crawling on the bottom holding the shell erect rather than dragging it along the substrate. This mode of life would have placed Polylopia in direct competition with many mobile gastropods and some cephalopods that carried their shells in a similar way.

Although the various lines of evidence are tenuous, collectively they are in accord with placement of Polylopia among the Hyolitha. The morphology of the genus may be distinct enough from other Hyolitha to require the use of a separate family-rank taxon. Marek (written commun., 1967) has suggested that the order Globorilida, currently assigned to the class Coniconchia, might be reinterpreted as an orthothecoid. If this supposition is correct, priority of familial and ordinal names could be affected. It is appropriate to defer any consideration of the family-rank taxon for Polylopia until Marek has published his findings. The conclusions on classification here presented are formally summarized as follows: 
Class Hyolitha Marek, 1963

Order Orthothecida Marek, 1966

Genus Polylopia Clark, 1925

Polylopia billingsi (Safford), 1869

\section{REFERENCES CITED}

Bassler, R. S., 1932, The stratigraphy of the central basin of Tennessee: Tennessee Div. Geology Bull. 38, 268 p., 49 pls.

Billings, Elkanah, 1861, New species of Lower Silurian fossils. I. On some new or little-known species of Lower Silurian fossils from the Potsdam Group (Primordial Zone) : Montreal, Canada Geol. Survey, 24 p. [Also pub. in (1) Vermont Geol. Survey, 1861, Report on the geology of Vermont : Claremont, N.H., v. 2, p. 942-960; (2) Billings, Elkanah, 1865, Paleozoic fossils, v. 1 ; Canada Geol. Survey, p. 1-24.]

Clark, T. H., 1925, On the nature of salterella: Royal Soc. Canada Proc. and Trans., sec. IV, ser. 3, v. 19, p. 29-41, 2 pls.

Cooper, B. N., 1945, The Stones River equivalents in the Appalachian region: Jour. Geology, v. 53, p. 262-275.

Cooper, B. N., and Prouty, C. E., 1943, Stratigraphy of the lower Middle Ordovician of Tazewell County, Virginia : Geol. Soc. America Bull., v. 54, p. 819-886.

Cooper, G. A., 1956, Chazyan and related brachiopods: Smithsonian Misc. Colln., v. 127, 1024 p., 269 pls.

Emerson, W. K., 1962, A classification of the scaphopod mollusks : Jour. Paleontology, v. 36, p. 461-482, pls. 76-80.

Fisher, D. W., 1958, Polylopia Clark, an Ordovician scaphopod [Tenn.] : Jour. Paleontology, v. 32, p. 144-146, pl. 23.

1962. Small conoidal shells of uncertain affinities, in Moore, R. C., ed., Treatise on invertebrate paleontology. Part W, Miscellanea : New York, and Lawrence, Kans., Geol. Soc. America and Univ. Kansas Press, p. W98-W145.

Flower, R. H., 1952, New Ordovician cephalopods from eastern North America: Jour. Paleontology, v. 26, p. 24-59, pls. 5-10.

Kobayashi, Teichii, 1937, On Salterella oanaliculata and its allies: Japanese Jour. Geology and Geography, v. 14, p. 173-183.

Lochman, Christina, 1952, Trilobites, in Cooper, G. A., and others, Cambrian stratigraphy and paleontology near Ca- borca, northwestern Sonora, Mexico: Smithsonian Misc. Colln., v. 119, no. 1, p. 60-161, pls. 15-31.

Marek, Ladislav, 1966, Nové rody hyolitủ z českého ordoviku, new hyolithid genera from the Ordovician of Bohemia: Časopis Národnho Muzea oddíl přírodovědný, v. 135, p. 89-92 [Title and abstract in Czech; text in English].

Marek. Ladislav, and Yochelson, E. L., 1964, Paleozoic mollusk : Hyolithes: Science, v. 146, p. 1674-1675.

Safford, J. M., 1869, Geology of Tennessee : Nashville, Tenn., S. C. Mercer, 551 p., 7 pls.

Schuchert, Charles, 1905, Catalogue of the type specimens of fossil invertebrates in the Department of Geology, United States National Museum: U.S. Natl. Mus. Bull. 53, pt. 1, $704 \mathrm{p}$.

Shimer, H. W., and Shrock, R. R., 1944, Index fossils of North America: New York, John Wiley \& Sons, 837 p., 303 pls.

Shrock, R. R., and Malott, C. A., 1933, The Kentland area of disturbed Ordovician rocks in northwestern Indiana: Jour. Geology, v. 41, p. 337-370.

Shrock, R. R., and Raasch, G. O., 1937, Paleontology of the disturbed Ordovician rocks near Kentland, Indiana: Am. Midland Naturalist, v. 18, p. 532-607, pls. 1-11.

Spath, L. F., 1936, So-called Salterella from the Cambrian of of Australia: Geol. Mag., v. 73, p. 433-440.

Teilhard de Chardin, Pierre, 1931, On an enigmatic pteropodlike fossil from the Lower Cambrian of southern Shansi, Biconulites grabaui, nov. gen., nov. sp.: China Geol. Soc. Bull., v. 10, p. 179-184, 2 pls.

Wilson, C. W., Jr., 1949, Pre-Chattanooga stratigraphy in central Tennessee: Tennessee Div. Geology Bull. 56, 407 p., 28 pls.

Yochelson, E. L., 1961a, The operculum and mode of life of Hyolithes: Jour. Paleontology, v. 35, p. 152-161, pls. 33-34. 1961b, Notes on the class Coniconchia: Jour. Paleontology, v. 35. p. 162-167. 1963, Problems of the early history of the Mollusca: Internat. Zool. Cong., 16th, Washington, Aug. 20-27, 1963, Proc., v. 2, p. 187.

Zazvorka, Vlastislav, 1930, Revision of the Hyolithi from $d \gamma$. Translated from the Czech original by T. Oakes Hirst: Česká Akad. věd a Umĕni, Třida II, Paleontographica Bohemiae, no. 13, p. [23]-44, 3 pls. 

PLATE 1 


\section{PLATE 1}

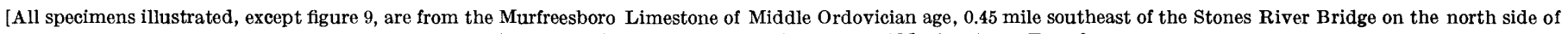
a new interstate highway leading northwest out of Murfreesboro, Tenn.]

Figures 1-8. Polylopia billingsi (Safford).

1. Bedding surface of small slab after solution in acid $(\times 11 / 2)$; USNM 157891.

2. One specimen inside a larger one $(\times 5)$; USNM 157892.

$3 \mathrm{a}, \mathrm{b}$. Two views of a silicified specimen with juvenile part broken and rehealed by silica, showing angulation at break (X 5); USNM 157893.

4a, b. Two views of another broken and healed silicified specimen (X 5); USNM 157894.

5 . View of nested shells at top of slab shown in figure $1(X 4)$.

6. View of nested shells in left part of slab shown in figure $1(\times 4)$.

7a, b. Top and side views of a small specimen symmetrically inside a larger one (X 3); USNM 157895 .

8. Side view of a small specimen, asymmetrically inside a larger on $(\times 3)$; USNM 157896.

9. Biconulites hardmanni (Foord).

Thin section parallel to longitudinal axis $(\times 5)$. From Lower Cambrian at Ord River Station, East Kimberley, West Australia. USNM 96652.

10-14. Polylopia billingsi (Safford).

10. Thin section parallel to longitudinal axis showing closed tip; apical part filled with a darker matrix than remainder of cavity $(\times 2.5)$; USNM 157897.

11. Thin section parallel to longitudinal axis showing one shell nested in another and three small specimens within that cavity $(\times 20)$; USNM 157898.

12. Thin section parallel to longitudinal axis showing multinested specimens to right $(X 2.5)$; USNM 157899 .

13. Same thin section as figure 11, showing associated organic debris $(\times 2.5)$.

14. Thin section slightly oblique to transverse section showing four nested specimens and one unnested specimen within the second cavity $(\times 20)$; USNM 1578900 

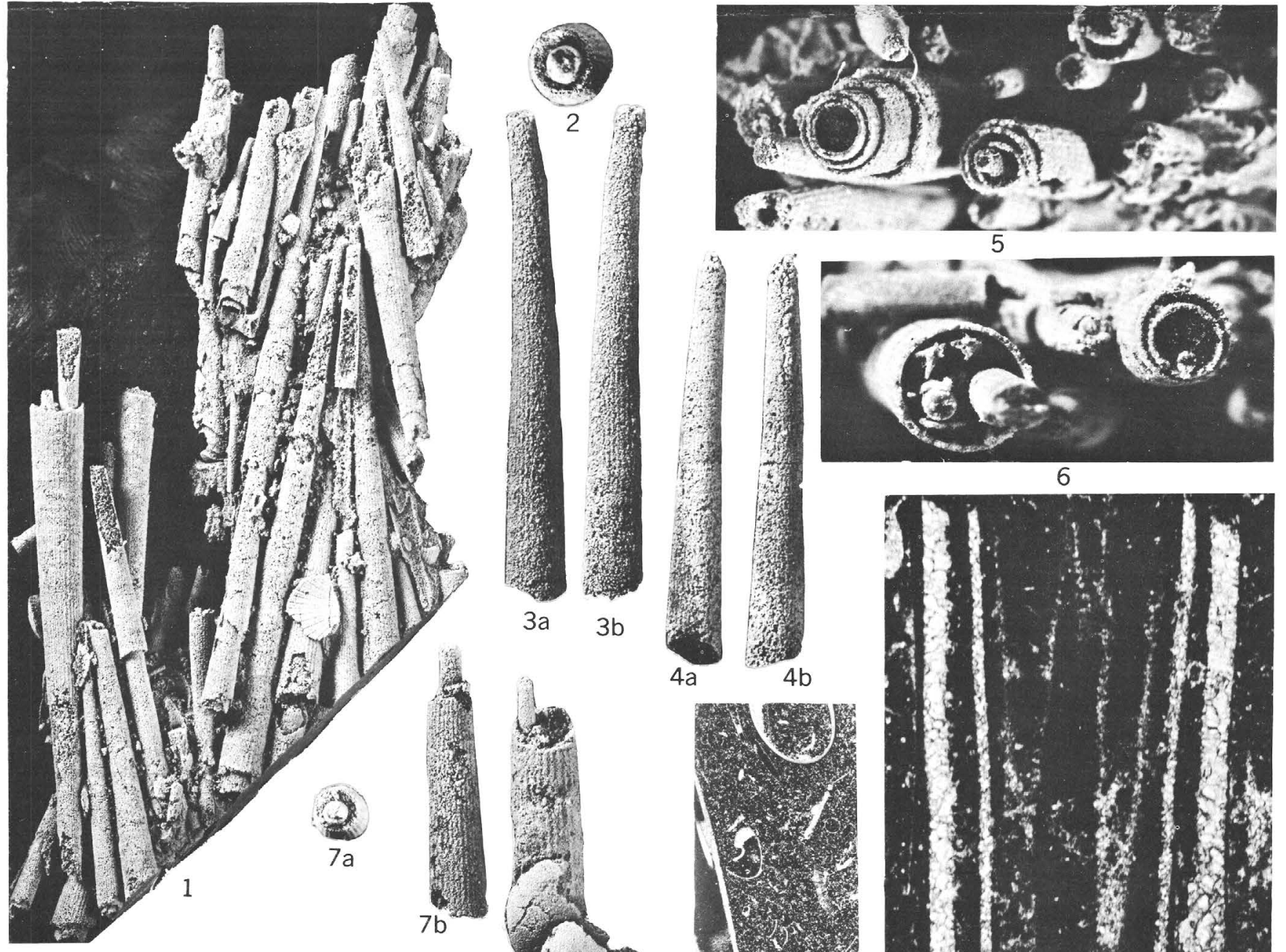

PROFESSIONAL PAPER 593-F PLATE 1

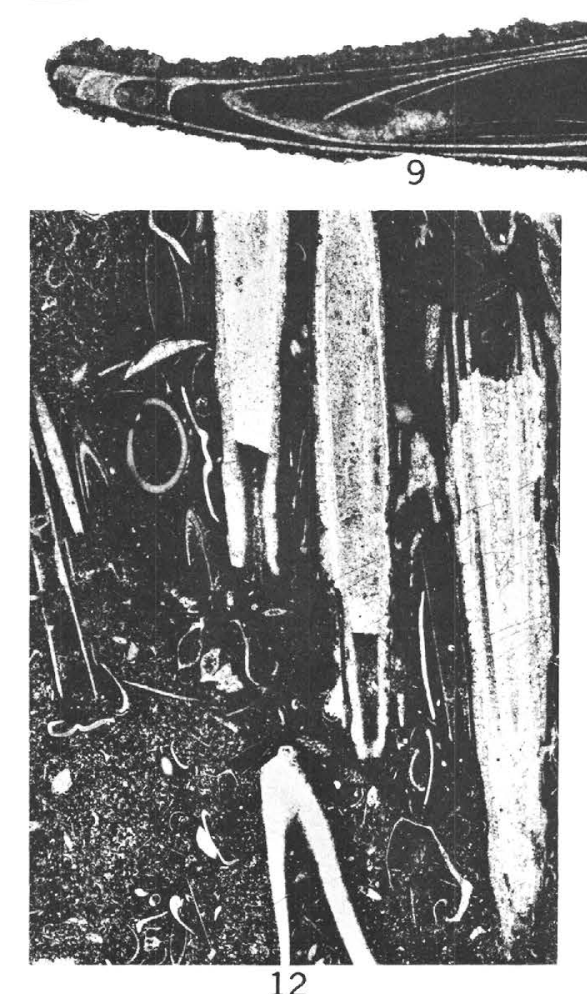

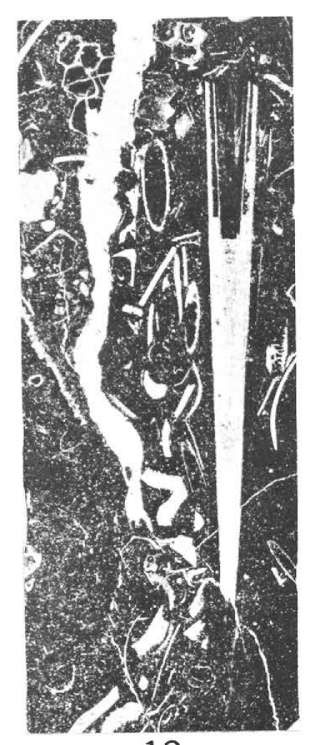

13

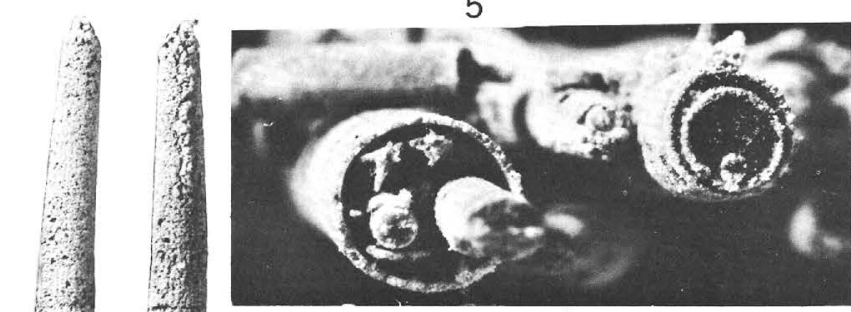

6
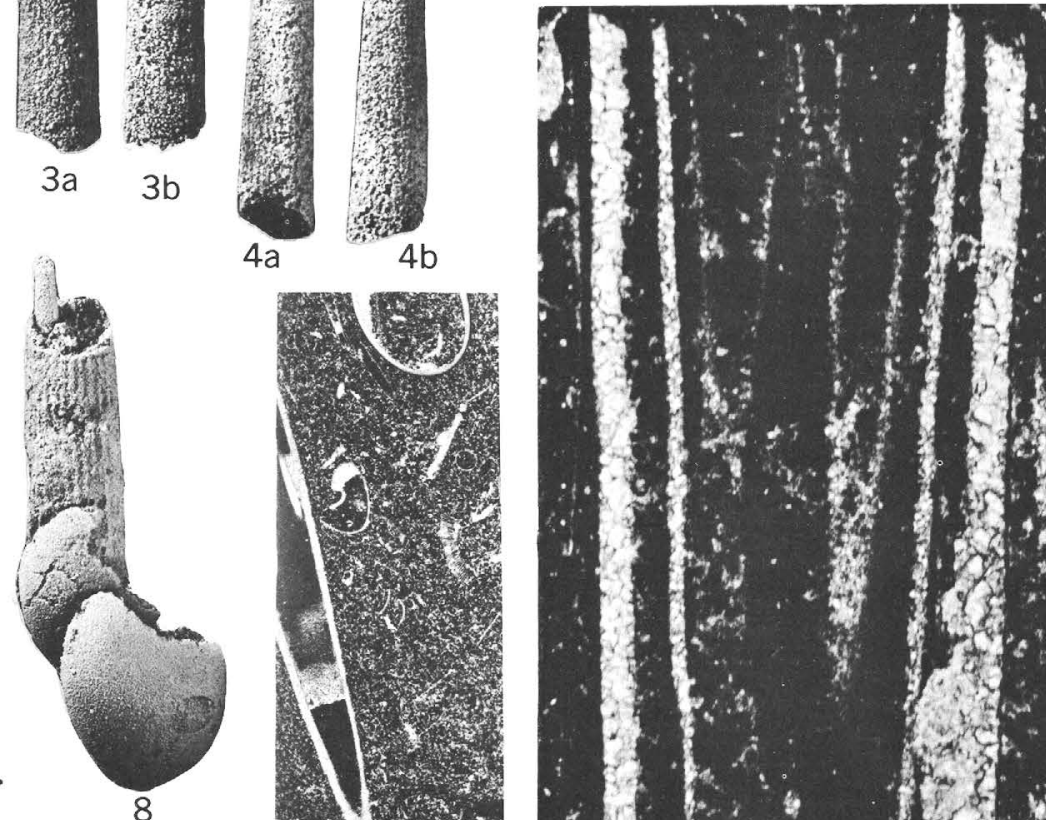

$4 \mathrm{~b}$

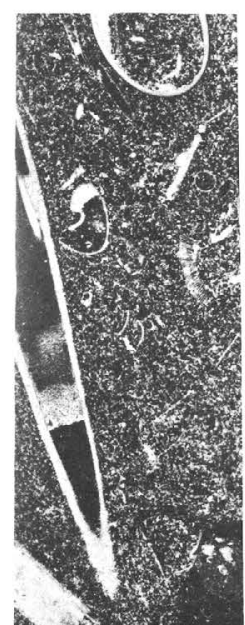

10

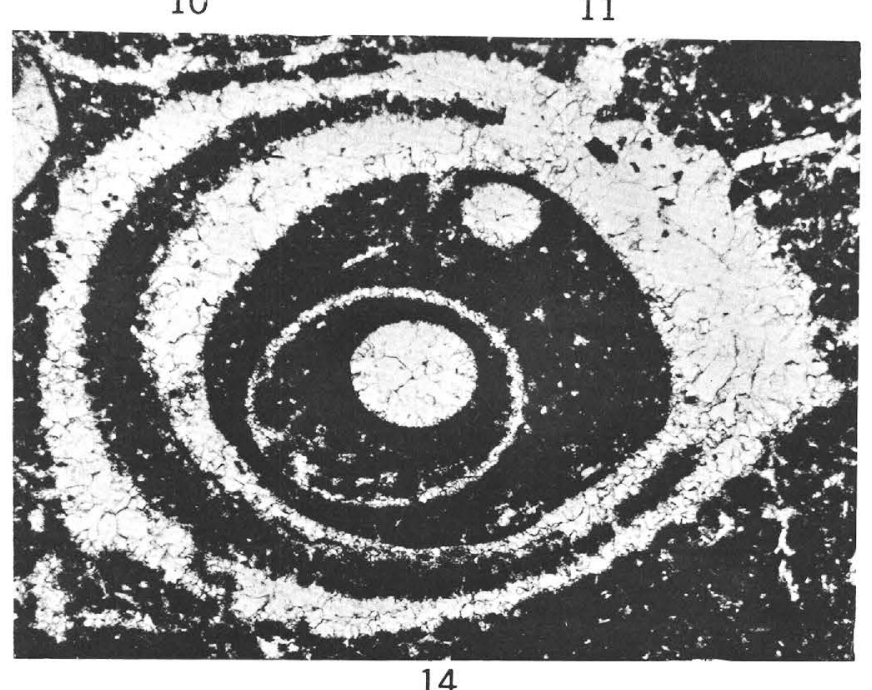

14

POLYLOPIA AND BICONULITES 
